\title{
Effects of the 21st Century Learning Model and Problem-Based Models on Higher Order Thinking Skill
}

\author{
Tumas YULIANTO ${ }^{1}$, Ikrar PRAMUDYA², Isnandar SLAMET ${ }^{3}$
}

\section{ARTICLE INFO}

\section{Article History:}

Received 20.03.2019

Received in revised form

03.10.2019

Accepted

Available online 01.12.2019

\begin{abstract}
The 4.0 industrial revolution is an important topic that is currently being discussed in Indonesia. Industrial revolution 4.0 has an essential influence on education in Indonesia, known as Education 4.0. Instruction 4.0 includes four necessary skills called $4 \mathrm{C}$, namely the ability to communicate, collaborate, think critically, problem-solving, creative, and innovation. The 4C skills are summarised in the form of HOTS (Higher Order Thinking Skill) questions that are currently applied in Indonesia. However, in reality, mathematics learning about the application of HOTS questions made a decline in the national average of student scores. The researcher concluded that students and teachers had not found the right learning model for the HOTS problem. Therefore, the main focus of this research is to apply the 21st-century learning model and problem-based learning models and see how the effects of the 21st-century model and problem-based learning models on HOTS in mathematics. The method of data analysis in this study uses one-way univariate variance analysis.
\end{abstract}

(C) IJERE. All rights reserved

Keywords:

Education 4.0, 21st Century Learning Model, Problem Based Learning Model, HOTS.

\section{INTRODUCTION}

The Era of Education 4.0 is a big challenge that is hard for teachers and educators in this era. The big problem for teachers in the Education 4.0 era is to prepare students to be able to compete with machine technology. (Whiting, 2018) quote Jack Ma Ceo Alibaba Group statement at the World Economic Forum 2018 annual meeting stated that Education is the toughest challenge of the century, If it does not change the way to educate and teach according to the times, it can be ascertained that in the next 30 years we will experience considerable difficulties.

Challenge Based Learning is a framework for learning while completing real-world challenges (Inc Apple, 2009) This framework is collaborative and direct, involving all participants (students, teachers, families, and community members) to identify big ideas, ask right questions, find and solve challenges, gain in-depth subject knowledge, develop 21st century skills, and share their thoughts with the world. (Nawawi, 2016) Challenge Based Learning learning models include the use of problems in the real world, where students can apply knowledge and problem-solving skills. (Johnson \& Adams, 2011) The Challenge Based Learning learning model is a model that combines essential aspects such as problem-based learning, projectbased learning, and contextual learning (CTL) that is focused on real problems in the world. (Johnson e. a., 2009) This learning makes problem-solving a significant concern, giving access to 21st-century equipment, requiring students to work collaboratively and manage time under the guidance of the teacher.

PBL learning model is by the purpose of mathematics learning, which focuses on thinking or reasoning, developing creative activities, developing problem-solving skills, and communicating ideas. (Argaw, Haile, Ayalew, \& Kuma, 2016) based learning as a learning strategy that simultaneously develops problem-solving strategies, disciplinary knowledge, and skills in placing students in activities to solve problems by confronting structural issues in the form of real problems in everyday life. (Ikman, Hasnawati, \& Rezky, 2016) Citing the conclusions of Pierce and Jones in PBL implementation, there is a process that must be raised, such as involvement (involvement), investigation and investigation, performance, general questions and discussion (question and answer). Strengthened by the results of the study, Qomariyah (2018) stated that the PBL learning model had a significant positive impact on the learning outcomes of XI IPS students compared to conventional learning models.

CTL Learning Model is a learning model whose approach can explore student interest and increase activity in the classroom by connecting subject matter content to real-world situations and motivating

${ }^{1}$ Corresponding e-mail: tumasyulianto17@gmail.com, Sebelas Maret University, ${ }^{1}$ https://orcid.org/0000-0003-0891-0802 ${ }^{1}$

${ }^{2}$ Corresponding e-mail: Ikrarpramudya@staff.uns.ac.id, Sebelas Maret University ${ }^{2}$, https://orcid.org// /0000-0002-5081-004X

${ }^{3}$ Corresponding e-mail: isnandarslamet@staff.uns.ac.id, Sebelas Maret University ${ }^{3}$, https://orcid.org/ $/^{3}$ 0000-0003-4931-4046 
students to make connections. In line with the opinion of (Nawas, 2018) which cites the conclusions of Jhonson CTL is a learning model that seeks to associate subject content with real-world situations and motivate students to connect the knowledge, they have with their daily lives. Also, (Nurhadi, Yasin, \& Senduk, 2004) concluded that in their study CTL is a learning model that helps students connect substance topics to real conditions and encourages them to make connections between material and that application for their lives. (Surdin, 2018) CTL learning model has advantages such as (1) learning becomes more meaningful and real, meaning students are required to be able to capture the relationship between learning experiences in school and real life. One step of the CTL learning model is an inquiry, where inquiry steps are an essential factor in the learning process. Janah \& Subroto (2018) inquiry has a significant influence on students to develop the knowledge they have understood, foster student creativity and stimulate students to learn to express their opinions, provide comprehensive experiences, facilitate students to learn to improve student learning outcomes.

How do we measure that the model is said to be successful in improving the quality of capabilities needed in the 21st century? Before we discuss this, 21st-century capabilities can be measured by seeing how students can communicate, collaborate, think critically, do problem-solving, have creativity and innovation. The ability to communicate, collaborate, think critically, do problem-solving, have creativity, and change can be measured by seeing how the students' high-level thinking skills value in mathematics. By learning mathematics, these abilities can be easily measured because mathematics is learning that needs the ability to think critically. The ability to think higher or commonly known as HOTS is a thought process that requires students to manipulate information and ideas in specific ways that give them new insights and implications (Gunawan, 2012).

HOTS is a process of thinking students in higher cognitive levels developed from various concepts and cognitive methods and taxonomy of learning such as problem-solving methods, bloom taxonomy, and taxonomy of learning, teaching, and assessment (Saputra, 2016). HOTS is a way of thinking that is no longer just verbalistic memorisation but also means the essence of what is contained, among other things, to be able to interpret the meaning that is integralistic thinking by analysing synthesis, associating to conclude the creation of creative ideas and products (Ernawati, 2017). HOTS involves the ability to solve problems, the ability to think creatively, think critically, the ability to argue, and the ability to make decisions guided by truth ideas, each of which has meaning. Therefore, it can be concluded that HOTS in this study is a highlevel thinking ability that is not just remembering, restating, or referring without processing, but high-level thinking skills to critically analyze information, transfer one concept to another, creative, creative and able to solve problems based on ideas or ideas constructed from within the students themselves based on real issues.

The most common taxonomy of learning in the cognitive domain is the taxonomy of bloom. In the table. 1. (Anderson, Lorin W; Krathwohl, David R, 2010) classify the dimensions of the thinking process as follows.

Table. 1. Dimensions of the Thinking Process

\begin{tabular}{|c|c|c|}
\hline \multirow{3}{*}{$\begin{array}{l}\mathrm{H} \\
\text { OTS }\end{array}$} & $\begin{array}{l}\text { Creative } \\
\text { (C6) }\end{array}$ & $\begin{array}{l}\text { - Create your ideas/ideas } \\
\text { - Verbs: construct, design, create, develop, write, } \\
\text { formulate }\end{array}$ \\
\hline & $\begin{array}{l}\text { Evaluate } \\
\text { (C5) }\end{array}$ & $\begin{array}{l}\text { - Make your own decisions } \\
\text { - Verbs evaluate, judge, refute, decide, choose, } \\
\text { support }\end{array}$ \\
\hline & $\begin{array}{l}\text { Analysing } \\
\text { (C4) }\end{array}$ & $\begin{array}{ll}\text { - } & \text { Specify aspects / elements } \\
\text { - } & \text { Verbs: compare, examine, criticise, test }\end{array}$ \\
\hline
\end{tabular}

High-level thinking skills in this study are at the level of reasoning that includes the dimensions of the thinking process of analysing (C4), evaluating (C5), and creating (C6). 
The work steps of the Challenge-Based Learning, (Premsmith, Jakkrit; Wannapiroon, Panita; Nilsook, Prachyanun, 2016) learning model that follow Apple inc as follows:

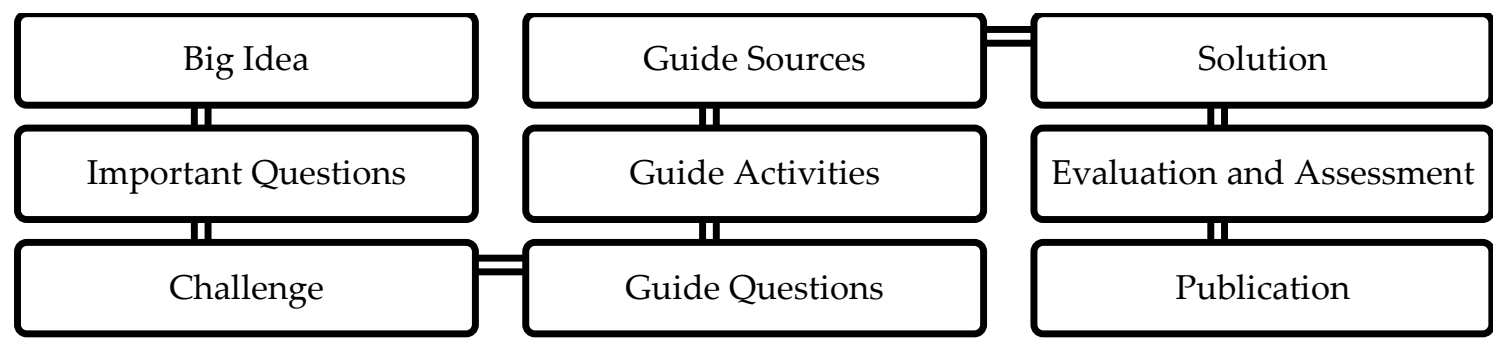

\section{Situation of the Problem}

Based on the results of the research and observation of the teacher and students, they still have not found the right way of learning in teaching and learning mathematics that is fun and gives sensations. Dull and rigid learning is very often seen, especially in remote areas. The learning model used only directly without encouragement for students to be able to show their strengths. Therefore, it is essential to research to find ways in which teachers and students find harmonious relationships in the teaching and learning process that are mutually beneficial to each other. The learning model that will be used is a factor that needs to be considered in the teaching and learning process because of that, the relationship between the teacher and students can be formed.

\section{Aim of the Study}

The purpose of this study was to find out how the effects of the 21st-century learning model and problem-based learning models on students' high-level thinking abilities. Therefore there will be experimentation on challenge-based learning models, problem-based learning, and contextual teaching and learning.

\section{METHOD}

This study is quasi-experimental research (quasi-experimental research), namely research conducted intentionally to try the independent variables to determine the differences in the use of cooperative learning models type CBL, PBL and CTL on HOTS students. Experimentation of challenge-based learning, problembased learning, and contextual teaching and learning will be conducted to 9 classes with a total of 279 students. The study sample was a grade VIII junior high school student, with an age range of 14-15 years (sample features can be seen in Table 2). Before testing, it is necessary to do a balance test on students 'highlevel thinking abilities to see how students' fundamental skills. The balance test was conducted to determine the strength of senior thinking students to use the pretest instrument, which included the student HOTS indicator. After a balance, an analysis is carried out, and the population has the same balance, the initial conditions are met. After that, the challenge-based learning model experiment and other models were carried out for four months in the study sample, at the end of the lesson, HOTS students were tested for the data to be tested. Other test requirements that will be carried out are the normality test, data homogeneity test, variance analysis test, and multiple comparison test, which is a test requirement for univariate one-way variance analysis.

Table 2. Sample Information

\begin{tabular}{ccccccccc}
\hline \multirow{2}{*}{ School Name } & \multicolumn{2}{c}{ CBL } & \multicolumn{2}{c}{ PBL } & \multicolumn{2}{c}{ CTL } & Total \\
\cline { 2 - 7 } & Class & Total & Class & Total & Class & Total & \\
\hline SMP N 8 Surakarta & VIIIE & 32 & VIIIF & 30 & VIIIG & 32 & 94 \\
SMP N 16 Surakarta & VIIIC & 32 & VIIID & 30 & VIIIE & 32 & 31 \\
SMP N 26 Surakarta & VIIIA & 30 & VIIIB & 31 & VIIIC & 30 & 94 \\
\hline Total & & 94 & & 91 & & 94 & 279 \\
\hline
\end{tabular}




\section{RESULT, DISCUSSION, AND SUGGESTIONS}

Research data will be summarised in the table, which will be shown below. The summary analysis of the data is the balance test results, normality test results, homogeneity test results, results of variance analysis, and the results of multiple comparisons.

Table 3. Independent Samples Test Results

\begin{tabular}{|c|c|c|c|}
\hline & & \multicolumn{2}{|c|}{ HOTS } \\
\hline & & $\begin{array}{c}\text { Equal variances } \\
\text { assumed }\end{array}$ & $\begin{array}{c}\text { Equal variances not } \\
\text { assumed }\end{array}$ \\
\hline \multirow{2}{*}{$\begin{array}{l}\text { Levene's Test of } \\
\text { Equality of Variances }\end{array}$} & $\mathrm{F}$ & .017 & \\
\hline & Sig & .898 & \\
\hline \multirow{7}{*}{$\begin{array}{l}\text { t-test for Equality of } \\
\text { Means }\end{array}$} & $\mathrm{T}$ & -.032 & -.032 \\
\hline & Df & 183 & 182.946 \\
\hline & Sig. (2-tailed) & .975 & .975 \\
\hline & Mean Difference & -.04793 & -.04793 \\
\hline & Std. Error Difference & 1.52073 & 1.52073 \\
\hline & \multirow{2}{*}{$\begin{array}{l}\text { 95\% Confidence Interval of } \\
\text { the Difference }\end{array}$} & -3.04835 & \\
\hline & & 2.95249 & 2.95174 \\
\hline
\end{tabular}

Based on table 3, Levene's Test for Equality of Variances value on HOTS variable Sig $>0.05$, therefore, $\mathrm{HO}$ is not rejected which means because the probability value (significance) HOTS with equal variance assumed is 0.898 greater than 0.05 , so it can be concluded that the ability beginning of the same student.

Table 4. Normality Test Results

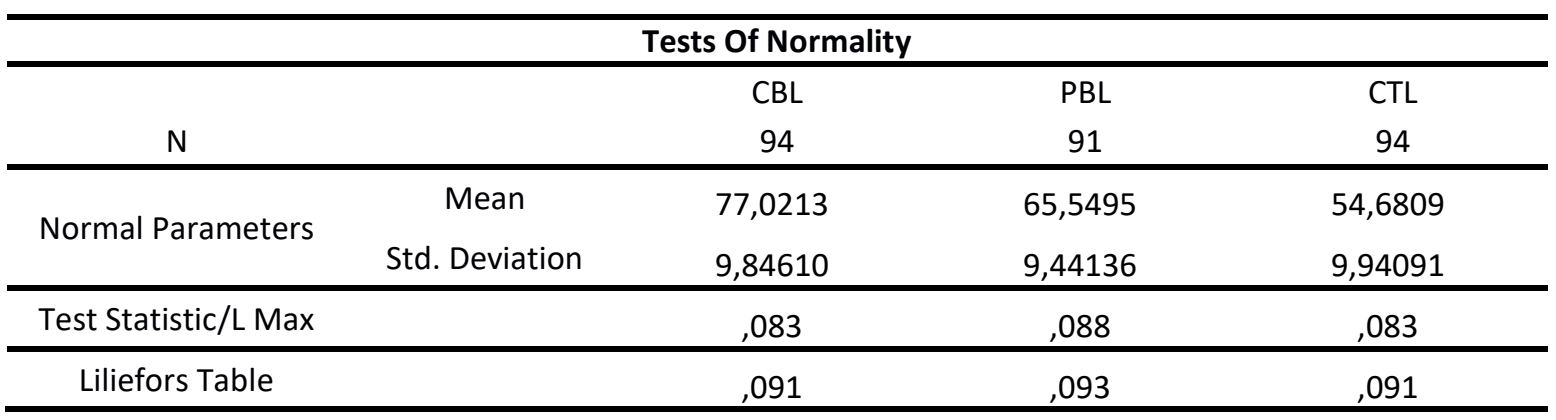

Based on table 4, obtained L Max CBL $=0.083$ less than critical area $\mathrm{L}(0.05 ; 94)=0.091$ then the decision of the $\mathrm{H} 0$ test is accepted, and the CBL population is normally distributed. Obtained L Max PBL $=0.088$ less than critical area $\mathrm{L}(0.05 ; 91)=0.093$ then the decision of the H0 test is accepted, and the PBL population is normally distributed. Obtained L Max CTL $=0.083$ less than critical area $\mathrm{L}(0.05 ; 94)=0.091$ then the decision of the $\mathrm{H} 0$ test is accepted, and the CTL population is normally distributed.

Table 5. Homogeneity Test Results

\begin{tabular}{cccccc}
\hline \multicolumn{7}{c}{ Test of Homogeneity of Variances } \\
\hline & Levene Statistic & df1 & df2 & Sig. \\
\hline HOTS & Based on Mean &, 332 & 2 & 276 &, 718 \\
\hline
\end{tabular}

Based on table 5, the value of $\mathrm{p}$-value $=0.718$ is higher than the cost of $\alpha=0.05$ because $\mathrm{p}>\alpha$, it can be concluded that homogeneity of variance is accepted, the variation of data in the CBL model, PBL model, and CTL models are the same. 
Table 6. Results of Variance Analysis (ANOVA)

\begin{tabular}{lccccc}
\hline \multicolumn{7}{c}{ ANOVA } \\
\hline HOTS & Sum of Square & Df & Mean Square & F & Sig. \\
\hline Between Groups & 24840,650 &, 332 & 12420,325 & 129,125 &, 000 \\
Within Groups & 26538,059 & 276 & 96,189 & & \\
Total & 51388,710 & 278 & & & \\
\hline
\end{tabular}

Based on table 6 , it can be seen that $\mathrm{H} 0$ is rejected at $\alpha=0.05$ because $\mathrm{p}=0.000<0.05$, it can be concluded that the three learning models have different effects.

Table 7. Multiple Comparison Results

\begin{tabular}{|c|c|c|c|c|c|c|}
\hline \multicolumn{7}{|c|}{ Multiple Comparisons } \\
\hline \multicolumn{7}{|c|}{$\begin{array}{l}\text { Dependent Variable: HOTS } \\
\text { Scheffe }\end{array}$} \\
\hline \multirow{2}{*}{$\begin{array}{c}\text { (I) Model } \\
\text { Pembelajaran }\end{array}$} & \multirow[b]{2}{*}{$\begin{array}{c}\text { (J) Model } \\
\text { Pembelajaran }\end{array}$} & \multirow[b]{2}{*}{$\begin{array}{l}\text { Mean Difference } \\
(\mathrm{I}-\mathrm{J})\end{array}$} & \multirow[b]{2}{*}{ Std. Error } & \multirow[b]{2}{*}{ Sig. } & \multicolumn{2}{|c|}{ 95\% Confidence Interval } \\
\hline & & & & & $\begin{array}{l}\text { Lower } \\
\text { Bound }\end{array}$ & $\begin{array}{l}\text { Upper } \\
\text { Bound }\end{array}$ \\
\hline \multirow[t]{2}{*}{$\mathrm{CBL}$} & PBL & $12,11012^{*}$ & 1,44232 &, 000 & 8,5604 & 15,6598 \\
\hline & CTL & $22,97872^{*}$ & 1,43058 & ,000 & 19,4579 & 26,4995 \\
\hline \multirow[t]{2}{*}{ PBL } & CBL & $-12,11012^{*}$ & 1,44232 & ,000 & $-15,6598$ & $-8,5604$ \\
\hline & CTL & $10,86860^{*}$ & 1,44232 & ,000 & 7,3189 & 14,4183 \\
\hline \multirow[t]{2}{*}{ CTL } & $\mathrm{CBL}$ & $-22,97872^{*}$ & 1,43058 & ,000 & $-26,4995$ & $-19,4579$ \\
\hline & PBL & $-10,86860^{*}$ & 1,44232 &, 000 & $-14,4183$ & $-7,3189$ \\
\hline
\end{tabular}

*. The mean difference is significant at the 0.05 level.

Based on table 7. It can be concluded that:

(1) Between PBL models and CBL models have a mean difference of -12.11012. Shows that HOTS's ability with the CBL model is more effective than the PBL model.

(2) Between the PBL model and the CTL, the model has a mean difference of 10.86860 . Shows that HOTS's capabilities with PBL models are more effective than CTL models.

(3) Between the CBL model and the CTL model, it has a mean difference of 22.97872. Shows that HOTS's capabilities with the CBL model are more effective than the CTL model.

Based on some of the explanations above, the CBL learning model has a positive impact on high-level thinking skills (HOTS) significantly compared to PBL and CTL learning models.

Based on the test results described above the 21st-century learning model is very appropriate to be applied in learning, accurately the challenge-based learning model. Based on this study, the challenge-based learning model gives HOTS students significantly better than other models with an average difference of 12.11012 when compared to the PBL model and a mean difference of 22.97872 when compared to the CTL model. Therefore, educators need to know the application of appropriate learning models is very important in the 21st century because if there is no suitable learning model, future generations will have difficulty facing the development of the 21st century. Researchers suggest applying the challenge-based learning model on mathematics subjects that are used in everyday life, examples of geometry, series, graphs, and systems of linear equations. Because of the limitations of the researcher, it is expected to conduct extensive research again to also pay attention to the student attitude variable towards the challenge-based learning model because it allows there to be other influences from the student attitude variable towards the challenge-based learning model towards HOTS. 
Yulianto,T., Pramudya,I. \& Slamet,I. (2019). Effects of the 21st century learning model and problem-based models on higher order thinking skill.

International Journal of Educational Research Review,Special Isuue, 749-755.

\section{REFERENCES}

Anderson, L. W., \& Krathwohl, D. R. (2010). Kerangka Landasan untuk Pembelajaran, Pengajaran, dan Asesmen. Yogyakarta: Pustaka Pelajar.

Anderson, Lorin W; Krathwohl, David R. (2010). A taxonomy for learning, teaching, and assessing: A revision of Bloom's taxonomy of education objectives. New York: Addison Wesley Longman, inc.

Apple, I. (2008). Apple classrooms of tomorrow-today learning in the 21st century. California: Apple, Inc.

Argaw, A. S., Haile, B. B., Ayalew, B. T., \& Kuma, S. G. (2016). The effect of problem based learning (PBL) instruction on students' motivation and problem-solving skills of physics. EURASIA Journal of Mathematics Science and Technology Education. 13 (3), 857-871

Cheung, R., Cohen, J., Lo, H., \& Elia, F. (2011). Challenge based learning in cybersecurity education. International Conference on Security and Management.

Ernawati, L. (2017). Pengembangan High Order Thinking (HOT) Melalui Metode Pembelajaran Banking Dalam Pendidikan Agama Islam. International Conference on Islamic Civilization and Society (ICICS).

Gunawan, A. W. (2012). Genius Learning Strategy: Petunjuk Praktis Untuk Menerapkan Accelerated Learning. Jakarta: PT. Gramedia Pustaka Utama.

Hendriana, H., Slamet, U. R., \& Sumarmo, U. (2014). Mathematical connection ability and self-confidence (An experiment on Junior High School students through contextual teaching and learning with mathematical manipulative). International Journal of Education. 8 (1), 1-11.

Huda, M. (2012). Cooperative learning metode, teknik, struktur, dan model penerapan. Yogyakarta: Pustaka belajar.

Ikman, Hasnawati, \& Rezky, M. F. (2016). Effect of problem based learning (pbl) models of critical thinking ability students on the early mathematics ability. International Journal of Education and Research, 4 (7), 361-374.

Inc Apple. (2009). Challenge based learning: A classroom guide. California: Apple, Inc.

Janah, I. I. N, \& Subroto, W. T. (2018). Comparison of cooperative learning model with inquiry on student learning outcomes. International Journal of Educational Research Review, 4 (2), 178-182.

Johnson, e. a. (2009). Challenge-based learning: An approach for our time. Texas: The New Media Consortium.

Johnson, L., \& Adams, S. (2011). Challenge based learning: The report from the implementation project. Texas: The New Media Consortium.

Johnson, R. A., \& Wichern, D. W. (2007). Applied multivariate statistical analysis. New Jersey: Prentice-Hall.

Krathwohl, D. R. (2002). A revision of Bloom's taxonomy: An overview. Journal Theory into practice, 212-218.

Kurniati, Kusumah, Y. S. \& Sabandar, J. (2016). Mathematical critical thinking ability through contextual teaching and learning approach. Journal on Mathematics Education. 6 (1), 53-62.

Nawas, A. (2018). Contextual teaching and learning (ctl) approach through react strategies on improving the students' critical thinking in writing. International Journal of Applied Management Science. 4(7), 46-49.

Nawawi, S. (2016). Potensi model pembelajaran challenge based learning dalam memberdayakan kemampuan berpikir kritis. Jurnal Inovasi Pendidikan IPA. 3 (2), 212-223.

Nufus, H., \& Bahrun, M. D. (2018). Mathematical creative thinking and student self-confidence in the challenge-based learning approach. Journal of Research and Advances in Mathematics Education. 3 (2), 57-68.

Nurhadi, Yasin, B., \& Senduk, A. G. (2004). Pembelajaran Kontekstual dan Penerapannya dalam KBK. Malang: UNM Press.

Nurlaili, Afriansyah, D., \& Nuri , Y. A. (2017). Pengaruh Model Pembelajaran Challenge Based Learning Terhadap Kemampuan Berpikir Kritis Siswa Pada Materi Lingkungan Kelas X di SMA Negeri 4 Prabumulih. Jurnal Pena Sains. 4 (2), 97-104. 
Yulianto,T., Pramudya,I. \& Slamet,I. (2019). Effects of the 21st century learning model and problem-based models on higher order thinking skill.

International Journal of Educational Research Review,Special Isuue, 749-755.

Premsmith, J; Wannapiroon, P; Nilsook, P. (2016). System design of challenge-based learning management system. The 4th International Conference on Technical Education. Nov 24, 2016, 27-33.

Qoomariyah, S. N. (2018). Effect of problem based learning model improve student learning outcomes. International Journal of Educational Research Review. 4 (2), 217-222

Saputra, H. (2016). Pengembangan Mutu Pendidikan Menuju Era Global: Penguatan Mutu Pembelajaran dengan Penerapan HOTS (High Order Thinking Skills). Bandung: SMILE's Publishing.

Surdin (2018). The effect of contextual teaching and learning (ctl) models on learning outcomes of social sciences of the material of forms. The International Journal of Education and Research. 6 (3), 57-64.

Surya, E., \& Samosir, R. N. (2017). Pengaruh Problem Based Learning (PBL) Terhadap Kemampuan Pemecahan Masalah Matematika. Pendidikan Matematika. 2, 1-10.

Swiden, C. L. (2013). Effects of challenge based learning on student motivation and achievement. Montana: Montana State University.

Widana, I. W. (2017). Penyusunan Soal Higher Order Thinking Skill (HOTS). Jakarta: Departemen Pendidikan Dan Kebudayaan.

Whiting, K. (2018). Jack Ma Wants To Go Back To Teaching. https://www.weforum.org/agenda/2018/09/jackma-wants-to-go-back-to-teaching/

Zulaiha, S. (2016). Pendekatan Contextual Teaching And Learning (CTL) Dan Implementasinya Dalam Rencana Pembelajaran PAI MI . BELAJEA: Jurnal Pendidikan Islam. 1 (1), 41-60. 